\title{
The Influence of Digital Financial Services on the Financial Performance of Commercial Banks in Cameroon
}

\author{
Ngwengeh Brendaline Beloke \\ $\mathrm{PhD}$ student, Department of Management Sciences, \\ Faculty of Social and Management Sciences, \\ University of Buea, Republic of Cameroon \\ Messomo Elle Serge (AP) \\ Associate professor, Head of Department of Banking and Finance, \\ Faculty of Social and Management \\ Sciences, University of Buea, Republic of Cameroon \\ Mbu Sunday Agbor (PhD) \\ Head of Department of Management Sciences, \\ Faculty of Social and Management Sciences, \\ University of Buea, Republic of Cameroon
}

Doi:10.19044/esj.2021.v17n15p448

Submitted: 26 April 2021

Accepted: 21 May 2021

Published: 31May 2021
Copyright 2021 Author(s)

Under Creative Commons BY-NC-ND

4.0OPEN ACCESS

Cite As:

Ngwengeh B.B., Messomo E.S. \& Mbu S.A. (2021). The Influence of Digital Financial Services on the Financial Performance of Commercial Banks in Cameroon. European Scientific Journal, ESJ, 17(15), 448. https://doi.org/10.19044/esj.2021.v17n15p448

\section{Abstract}

A strong banking industry is important in every nation and this can have a significant effect in supporting economic development through the provision of efficient financial services. Digital banking/financial services is the act of carrying out financial transactions without the use of physical cash, coins or bills. This paper sort to determine the influence of digital financial services on the financial performance of commercial banks in Cameroon. Specifically, it examined the influence of Digital Savings Services, Digital Transfers Services, Digital Withdrawals Services and Digital Payment Services on the profitability of commercial banks in Cameroon. It covers 10 out of 15 commercial banks in Cameroon. Methodologically, it made use of survey research design. Item by item analysis of the questions was used to identify the reliability of digital financial services. The Taylor linearise variance estimation technique was used to determine their influence on 
commercial bank profitability. Results from the study showed that digital saving services, digital withdrawal services and digital transfer services have a positive and significant influence on the profitability of commercial banks in Cameroon. Digital payment on the other hand had a negative but significant influence on commercial Bank's Profitability at $10 \%$ level of significance. Generally, $48 \%$ of variations of profitability of commercial banks are caused by joint variations in the use of digital transfer services, Digital Savings services, Digital Withdrawal services and Digital Payment services. Consequently 0.52 or $52 \%$ of the variations in profitability are not accounted for by the study's model on digital financial services and bank profitability but caused by the error term. Conclusively, digital financial services are a booster of commercial bank's profit levels. Finally, the study recommended that management of banks and policy makers in the banking industry should go in for robust digital systems and services as a means to diversify their sources of income and meet up with declining profit levels.

Keywords: Digital Financial Services, Bank Profitability, Commercial Banks, Cameroon

\section{Introduction}

The need for every business is to be effective and efficient while profitably rendering services to their customers. As a result, the implications of Information and communication Technology (ICT) adoption and use for the global financial system have been fundamental. ICT has not only transformed transaction processes of rendering banking services but is also associated with shifting organisational boundaries, facilitating the creation of new financial products, changing the nature of work, globalising financial markets and restructuring the character of financial intermediation (Scott, Reenen and Zachariadis, 2017). With the emergence of consumer rights and rapid technological advancements in the 1960s, there was a significant shift in both retail and corporate banking. As a result of the dominant influence of customers, most of these processes now are being done electronically or via the bank's official website with complex algorithms, also known as Digitalisation or digital financial services giving rise to new customer preferences which banks must meet.

Information Technology opportunities and the landscape in rules and regulations are fast changing. Just a few months ago (as at the time of writing), a local bank in Iceland made the loan application process check possible in just three (3) minutes for individuals through the bank's mobile application. Before, the same process took the customer about ten days to complete. With this process, the bank has eliminated all physical contacts between bank officials and the customers, enabling the customer to request 
for the application at their convenience. Barry (2018) pointed out that, due to mobile banking services, the normal time for savings has reduced by $30 \%$ while that of withdrawals has reduced by $70 \%$. Most recent projections estimate that around $30 \%$ to $40 \%$ of all current service-related processes will be replaced with a digitalised workforce (Lamberton and Stephen, 2016). According to Porkelsson (2017) this shows that the need for human interference is getting less important and the use of automated processes, whether it's with artificial intelligence or other robotic automation, is rapidly taking over. Ayuketang (2018) noted that digital financial services have led to a situation in which information, communication and commerce are no longer limited by time and Geographical space.

By definition, digital financial service is the provision of a broad range of financial services that can be accessed and delivered through digital channels in order to execute financial transactions such as payments, savings, remittances and insurance (Kambale, nd). Today, Africa is home to more digital financial service deployments than any other region in the world. Ten years after the breakthrough of digital financial services in Sub-Saharan Africa, there is evidence of this, with about half of nearly 700 million individual users worldwide (LeHouerou, 2018). In the African continent, the digital financial service impacts on the financial sector can easily be linked to the amount of people using internet banking for settling their bills because it is the main factor for the average people in the banking errands (Pohjola 2015 as cited in Mueni, 2017).

The financial system in the Economic Community of Central African States (CEMAC) is bank dominated and mostly foreign owned. Cameroon and Gabon, the two largest economic powers in the sub-region, account for about three fourths (3/4) of total assets and loans (Saab and Vacher, 2007). At the end of the seminar on how to achieve financial inclusion and digital transformation of the banking and financial services sector in Cameroon profitably, Limunga (2019) recommended that it appears imperative for banks in Cameroon to go digital, as $60 \%$ of Cameroonians are unbanked, while about 9.5 million of them have already adopted mobile finance. This study examines the influence of Digital Savings Services, Digital Transfers Services, Digital Withdrawals Services and Digital Payment Services on the profitability of commercial banks in Cameroon.

\section{Statement of Problem}

The end of the great depression of 2007 has forced the banking industry to begin a process of fostering changes. Novel Business models based on technological advancements are challenging the existence of a long established and traditional industry (Ketterer, 2017). Perpetual vision engineered by performance orientation is a mandatory element for all 
businesses that operate for profit motives. Competition in the banking sector is toughening as days go by and without the introduction of new technologies into service mechanisms, even the strongest banks with a conservative strategy will lose a significant part of their customers and consequently their profit levels will shrink. As such digital financial services have become a major topic for banks all over the world. Belous and Lyalkov (2017) as cited in Galazova and Magnomaeva (2019) noted that by 2020 more than $20 \%$ of businesses in the financial service industry will be at risk due to the impact of the Financial Technology (FinTech) segment. This is because the traditional banking system has not been able to solve the modern day problem of low profit levels of commercial banks eroded by the stiff competition coming especially from the telecommunication industry. Lately, financial institutions have identified sustainability to be an important part of their projects which implies sustainable banking is a strong response to financial slumps. A change from traditional deposit taking and lending towards investments based on revenues from fee and commission services may be the answer to this challenge as commercial banks profit levels sink. Given the presence of many other non banking financial institutions rendering similar banking services, the amount of profits commercial banks made in the yesteryears have been reduced drastically by these institutions. This is due to the inability of the traditional banking system to make sufficient profit so as to withstand the prevailing competition. This is an indication that the traditional banking activities may no longer permit commercial banks to meet up with the unending and sophisticated demands from customers, to make sufficient profit in order to maximize shareholder's wealth, to respect regulatory limit of bank activities and the need to make sufficient profit for sustainability. It is from this backdrop that this study seeks to find out whether the adoption of digital banking services by commercial banks can serve as a solution to improve commercial bank's performance since the traditional banking system has remained dwarf in this aspect.

\section{Statistical Hypotheses}

The Statistical Hypotheses that guide the progress of this paper is; Digital Savings Services, Digital Transfers Services, Digital Withdrawals Services and Digital Payment Services have no influence on the profitability of commercial banks in Cameroon.

\section{Literature Review}

\section{Empirical Literature}

Here, existing Literature relating to digital financial services and the performance of commercial banks have been reviewed. This chapter presents 
a review of the most noteworthy contributors of other authors to the research area. The purpose of this review was to make a comparison with similar investigations. Ogare (2013) carried out a study on the effect of electronic banking on the financial performance of commercial banks in Kenya. The objective was to investigate the relationship between e-banking and the performance of commercial banks in Kenya. Electronic banking, the independent variable consisted of Automated Teller Machines (ATMs), Number of debit and credit cards issued to customers, Number of Point of Sales (POS) terminals and the usage of the levels of Mobile Banking, Internet Banking and Electronic Funds Transfers or Digital transfers. The study used secondary data collected from the annual reports of commercial banks and the Central Bank of Kenya from 2008 to 2012. To analyse data, descriptive and inferential statistics were used. Findings from the study shows that Automated Teller Machines (ATMs), Number of debit and credit cards issued to customers, Number of Point of Sales (POS) terminals and the usage of the levels of Mobile Banking, Internet Banking and Electronic Funds or digital transfers have a strong and significant effect on the profitability of commercial banks in the Kenyan banking industry. Thus there exist a positive relationship between e-banking and bank performance.

More so Sana, Mohammad, Hassan \& Momina (2011) carried out a study on the impact of e-banking on the profitability of Pakistini Banks. The aim of their paper was to determine if digital funds transfers and Automated Teller Machine (ATMs) play a role on bank's profitability. The research was qualitative and data for the study was gathered by interviewing bank managers of twelve banks across Pakistan. Results from their study show that ATMs and Digital Funds Transfer have increased the profitability of banks by enabling them to meet their costs and earn profit even in the short span of time.

Again, Boateng \& Nagaruju (2020)carried out research on the impact of digital banking on the profitability of deposit money banks; evidence from Ghana. The fundamental research objective was to find out the impact of digital banking on the profitability of deposit money banks in Ghana. Secondary data spanning from 2012 to 2018 were collected from the annual payment system report of the Central Bank of Ghana, Cheque Codeline clearing, Ghana Automated Clearing House, Ghana Interbank Settlement, Gh-Link (gh-link is a local electronic payment ecosystem based on the domestic Automated Teller Machines (ATM) card with channels such as ATM, PoS and Web.), E-zwich (E-zwich is the brand name for the National Switch and Smart card payment system) and Mobile Money Payments in value were the independent variables. Return on Assets (ROA) was the dependent variable employed in the study. Partial Least Square (PLS) regression was the statistical tool used for the analysis with the aid of 
Origin2018 scientific software. The results of the study indicated that GhLink and E-zwich distinguished themselves from the rest of the variables by explaining $95.87 \%$ of the variations in the profitability of Ghanaian banks. It was further found that a positive relationship existed between Cheque Codeline Clearing; Ghana Automated Clearing House, Ghana interbank settlement, GH-Link, and the profitability of Ghanaian Banks. Mobile money and E-zwich, on the other hand, had a negative relationship with the profitability of the banks.

Chindudzi et al., (2020) carried out research on the impact of digital banking on the performance of commercial banks in Zimbabwe. The main objective of their study was to investigate the impact of digital banking on the performance of commercial banks in Zimbabwe. Making use of annual secondary data for the period 2013 to 2017 obtained from the bank's annual financial report and publications, four digital banking variables were used. They include; online customer deposits or Digital savings, Online Banking Transactions, Internet Fees and Commissions and Internet Banking Expenditure while Return on Assets (ROA) was used as the measure of financial performance. Panel Data Analysis (the random effect regression model) and the Pearson's Product Moment Correlation analysis were employed as the statistical data analytical tool. The study established that digital banking has contributed positively to the performance of Zimbabwe's commercial bank through increase online deposits or savings and banking transactions. Generally, the study found that electronic banking usage universally and significantly influences the financial performance of commercial banks as measured by ROA.

Wadesango \& Magaya (2020) carried out a study on the impact of digital banking services on the performance of commercial banks in Zimbabwe. To accomplish this, the study made an attempt to investigate the effect of digital banking on financial performance of commercial banks in Zimbabwe. Quantitative research methodology was adopted. The target population for the study was one commercial bank. Data collection sheet was used in data collection. Pearson correlation coefficient helped evaluate the effect of digital banking on the banks' financial performance. Inferential test and multiple regression analysis were used to analyse the effects of digital banking on financial performance. The study revealed that ROA in commercial bank in Zimbabwe increased in upwards trends due to an increase in online customer deposits through digital banking platforms. The study established that online bank transaction to total asset ratio increased in an upwards trend over the specified study period. Further increase in Information and Communication Technology (ICT) expenses, fees and commissions to total asset ratio increased. 
Again, Takon et al., (2019) in their paper examined the impact of the digital payment system on the efficiency of the Nigerian Banking Sector. The objective of their paper was to examine the contribution of the digital payment system on the efficiency of the banking sector in Nigeria. Quarterly data covering 2009-2018 were generated from the Central Bank of Nigeria (CBN) Statistical Bulletin and World Bank database. They employed the Ordinary Least Square (OLS) regression, after testing for the properties of time series using Augmented Dickey-Fuller (ADF) and PhilpPeron test of stationarity. Engle and Granger test for co-integration were conducted to determine the existence of a long run relationship. The speed of adjustment was determined using the Error Correction Model (ECM). The result of the study shows that digital payments proxied by Automated Teller Machine (ATM) transactions, Point of Sales (POS) transactions, Mobile Payment (MP) transactions and Web Payment (WP) Transactions has negative and significant impact on bank efficiency proxied by bank overhead cost both in the long and short run. The effect of digital payment on total cost as a ration of income varies according to the variable used to proxy digital payment.

Vekya (2017) study was on the Impact of e-banking on the profitability of commercial banks in Kenya. The study sought to determine the impact of electronic banking on the profitability of commercial banks in Kenya. Methodologically, the study adopted a descriptive research design. The population of the research consisted of the 43 commercial banks in operations as at 31st 2014 in Kenya. A census survey was undertaken. The study used secondary data obtained from various Central Banks of Kenya publications. Statistical Package for Social Sciences (SPSS) was used in the analysis of data. Descriptive statistics produced trends, means and percentages while inferential statistics produced regression and correlation results which showed the causal relationship among the variables. Results from multiple regression indicated that there is a positive significant relationship between ATM transactions (Digital withdrawals) and bank profitability $(\mathrm{p}<0.05-0.004)$. A unit increase in digital withdrawal leads to an increase in ROE (bank profitability) by 1.662 units.

Furthermore, Kemboi (2018) carried out research on the relationship between Financial Technology and the financial performance of 43 commercial banks in Kenya. The objective of the study was to determine the effect of financial technologies on the financial performance of commercial banks in Kenya. In this study, the independent variables were mobile banking, internet and agency banking. The target population for this study was the 43 banks in Kenya. The study used descriptive statistics analysed using the Statistical Package for Social Science (SPSS) software, multiple regression technique was also used to 
study the relationship between financial performance and financial technology. Results from the study shows that adoption of mobile banking, Online or internet banking and agency banking impacted the financial performance measured using return on assets for banks positively.

In addition, Karmal et al., (2017) carried out a study on Electronic Card Usage and their Impact on Bank's Profitability in Jordanian Banks. The Purpose of this study was to know the effect of using the electronic credit cards such as the Number of Electronic Credit Cards, the proportion of Investment in Credit Cards, and the Operational Expenses to the Credit Cards. They explain their effect on the net Income from Credit Cards on bank's profitability by using a return on equity model. The information and data were collected from Annual reports given by the banks and from the credit management of Commercial banks. To analyze the study data and to test its hypothesis, the Statistical Package for Social Science (SPSS) system was used. Moreover, in order to answer the Questions of this study, a simple Regression was used. Their study found out that there is an effect between the numbers of credit cards on banks profitability. Furthermore, there is an effect on the net income from Credit Cards and proportion of investment in Credit Cards. Moreover, there is an effect between operation expenses on Credit Cards and net income from Credit Cards. There is also a positive effect between net income from Credit Cards and profitability (ROE).

Again, Alubisia et al., (2018) carried out a study on the effect of technology based innovation on non interest income of commercial banks in Kenya. The purpose of the study was to identify the impact of technology based financial innovation on non-interest income in Kenyan commercial banks. The study investigated how the adoption of Automated Teller Machines (ATMs) and Cards, Internet and Mobile Banking and use of Funds Transfer Systems such as Gross settlement system (RTGS) and Electronic Funds Transfer (EFT) has impacted the non-interest income of commercial banks in Kenya. Descriptive research design was utilised. The study found that technology based financial innovation has a significant effect on the non interest income earned by commercial banks in Kenya.

\section{Theoretical Literature}

In this section, the paper reviewed the most prominent and adopted theory in line with the study's area of interest. The theory reviewed one of the prominent financial innovation theories. Financial innovation theories are based on the tenet that banks carry out innovative financial services due to circumstances surrounding them. In reaction to these harsh circumstances they are pushed to carry out more innovations so as to make more profit and be sustainable. The Updated DeLone and McLean Information System (IS) 
Success model was adopted and extended in this paper to reveal the variables of interest.

\section{Updated DeLone and McLean Information System (IS) Success Model}

The updated model offers six interrelated constructs of information systems success measures, that is, the quality dimensions (information quality, system quality, and service quality) which could affect subsequent use or intention to use and user satisfaction. It also suggested that some benefits tagged as net benefits will be achieved as a result of use and/or user satisfaction. These net benefits could consequently affect user satisfaction and continued use of the system. Put together, these six constructs are; Information, system, and service quality; use, user satisfaction, and net benefits.

In extending this model, this paper included the outcome of a successful information system for commercial banks. It explains that, if a bank's information system is successful, then the result will be digital withdrawal services, digital saving services, digital payment services and digital transfer services and this will have a net benefit impact on the bank in terms of increased bank profitability. This can be seen from the diagram below;

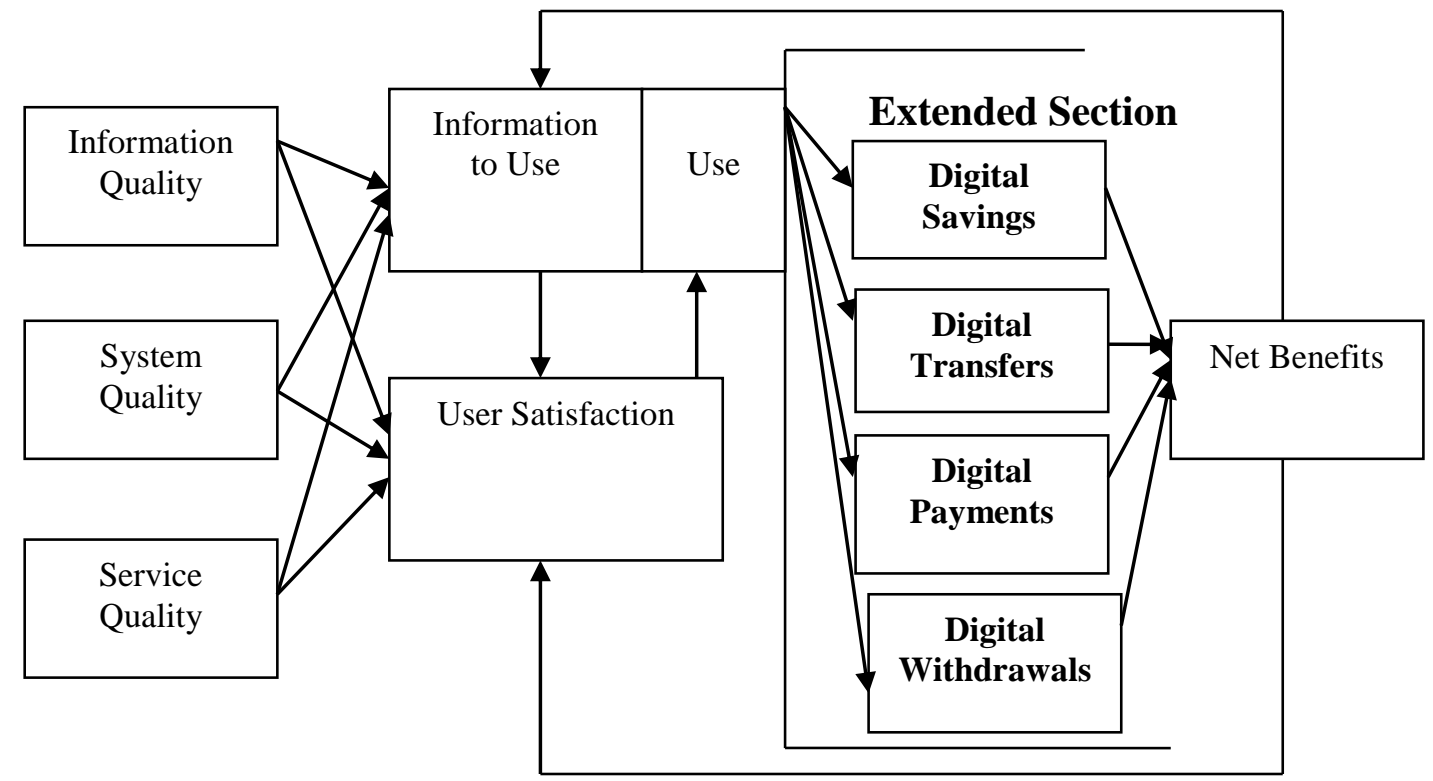

Figure 1.Extended Updated DeLone and McLean IS Success Model Source: Researchers (2021) 


\section{Materials And Methods \\ Methodological Steps}

The main aim of this paper was to determine the influence of digital financial services on the profitability of commercial banks in Cameroon. To test the hypothesis, the following is a list of the methodological steps that were employed;

Step I: Type of research: Quantitative research specifically causal research suitable to establish cause effect relationships among variables.

Step II: Target Population of the study: The study's target population encompassed all employees working in the electronic banking department at the Headquarters of all 15 commercial banks in Cameroon. On average there were 3 staff working in the electronic banking department per bank.

Step III: Sampling Size and Sampling Technique. Questionnaires were administered to 30 bank staff from the 10 commercial banks under study. An average of 3 bank staff was used giving a total of 30 respondents who work in the Head Office of Commercial Banks. The Head office was used because digital banking data is highly centralized for all commercial banks and so reliable information could only be obtained from the Head Quarters of Banks. This paper made use of the non-probability sampling technique specifically purposive sampling. The purposive sampling technique, also called judgment sampling, is the deliberate choice of a participant due to the qualities the participants possess.

Step IV: Test for reliability and Validity of Research constructs/instruments; an item by item internal consistency test was carried to determine the reliability of the constructs while content validity was used to test for the validity of the constructs under study.

Step V: Administration of questionnaires to bank staff working in the electronic banking department.

Step VI: Data Collection: Data from the questionnaire was recorded and coded in statistical package for social science (SPSS) for analysis to facilitate analysis.

Step VII: Regression Model Used: The model used in this paper was adopted and modified from a similar study by Ngumi (2013).

Step VIII: Method of Data Analysis: Data for this paper was anaylised using multiple regression. Regression studies are excellent tools when you need to make predictions and forecast future trends.

Step IX: Estimation Technique: Taylor linearised variance estimation technique was chosen over the ordinary least square technique because it is suitable for complex survey data and a survey data usually does not fulfill some of the assumptions of Ordinary Least Square such as homoscedasticity. 


\section{Data Collection}

This study adopted a survey research design by issuing questionnaires to specific bank staff particularly those working in the electronic banking department. This study made use of the non-probability sampling technique specifically purposive sampling. The purposive sampling technique, also called judgment sampling, is the deliberate choice of a participant due to the qualities the participant possesses. Simply put, the researcher decides what needs to be known and sets out to find people who can and are willing to provide the information by virtue of their knowledge or experience. The idea behind purposive sampling is to concentrate on people with particular characteristics who will better assist with the relevant information(Etikan, Musa \& Alkassim, 2016).

As a result, only those who work in the electronic banking department at the Head Office of all commercial banks under study were chosen to respond to the questions in the questionnaire. They were chosen because this department is a technical department of the bank that is able to monitor and record the volume of digital financial transactions in the bank. Again, they are able to use the information for decision making identifying those digital financial services that are mostly used by bank customers (i.e. Digital payments, Digital Savings, Digital Withdrawals and Digital Transfers). They also seek ways of improving their uses. They were also selected because they are in charge of implementing strategic decisions for banks and have higher level of appreciation on how digital financial services influences the performance of their institutions.

In this department, there were 18 Males and 12 Females workers for all the 10 commercial banks under study. This indicates that more men are employed than women in this department. Their ages range between 20 years to 40 years with the majority within the age range of $31-40$. Again, $43 \%$ of the respondents were holders of First Degree, 40\% were Master's Degree holders while $17 \%$ held certificates above Master's Degree. As per management levels, 6 of the respondents indicated that they are top level managers, 24 middle level managers while none was a Lower level manager. Out of the 15 commercial banks in Cameroon as at the time of writing this work, 10 were used for the study. They include; NFC Bank, Eco-Bank, SGBC Bank, CCA Bank, Afriland First Bank, UBC Bank, BICEC Bank, UBA Bank, Standard Chartered Bank, and Atlantic Bank. There were three respondents from each bank.

A total of 30 bank staff made up the sample size of this study representing $67 \%$ of the total population. All administered questionnaires were collected representing $100 \%$ response rate. The choice of primary data was based on the need for originality and the absence of secondary data. The questionnaires were designed using five point Likert scale questions to 
capture the constructs of digital financial services. For each of the constructs, a set of five questions were asked. An Item by Item test for reliability was carried out in order to give room for standard scientific analysis after ensuring content validity. The data was collected from the questionnaires using excel spreadsheet to give room for statistical analysis.

The time scope for this study is within a period of five years that spans from 2016 to 2021. The Geographical scope is limited only to Cameroon, specifically commercial banks offering digital financial services. In the light of content scope, the variables used in this study are limited only to transactions carried out using digital financial services such as digital savings, digital withdrawals, Digital Transfers and Digital savings services while performance of commercial banks is limited to financial performance. Theories and concepts reviewed in this study are those related to digital financial services innovation such as the financial innovation theories.

\section{Model of Analysis}

The analytical model that was utilized to examine the influence of digital financial services on the financial performance of commercial banks in Cameroon is as follows; an item by item internal consistency test was done to determine the reliability of the constructs. The table below shows a summary of the reliability test for the influence of digital financial services on the financial performance of commercial banks in Cameroon.

Table 1.Reliability statistics of constructs

\begin{tabular}{|c|c|c|}
\hline \multicolumn{2}{|c|}{ Reliability Statistics } \\
\cline { 1 - 3 } Aspects & \multirow{2}{*}{ Questions } & \multirow{2}{*}{ Cronbrach's Alpha } \\
\hline Overall & & 0.5493 \\
\hline Number of Cases & Q1-Q5 & 0.6087 \\
\hline No. of Items & Q6-Q10 & 0.9773 \\
\hline $\mathbf{2 5}$ & Q11-Q15 & 0.2840 \\
\hline & Q16-Q20 & 0.9105 \\
\hline
\end{tabular}

Specific Objective: To determine the influence of digital transfer services, digital payment services, digital withdrawal services and digital savings services on the profitability of commercial banks in Cameroon.

Given that the five point Likert scale questionnaire produced an ordinal scale data, the survey linearised regression model was used to assess the contribution of digital financial services on the profitability of commercial banks in Cameroon. Furthermore, the Taylor linearised variance estimation technique was chosen over the ordinary least square technique because it is suitable for complex survey data and a survey data usually does not fulfill some of the assumptions of Ordinary Least Square such as homoscedasticity. 
The survey linearised regression model for this study was adopted and modified from a similar work by Ngumi (2013). This can be simplified as follows;

Prof $=f(\mathrm{DFS}+\mathrm{e})$

Prof $=\mathrm{a} 0+\mathrm{a}_{\mathrm{i}} \mathrm{DFS}_{\mathrm{i}}+\mathrm{e}$

Where a priori: ai $>0$, at $10 \%$ level of significance and $90 \%$ confidence interval

\section{Techniques of data analysis}

The objective of this paper was to determine the influence of digital financial services on the financial performance of commercial banks in Cameroon. To meet these objectives, the variables identified from related literature were further estimated using the Taylor linearized variance estimation technique. The need to generalize and to establish the findings gave the need to carry out multicollinearity test of variables using the Variance Inflation factor

\section{The Correlation Matrix}

Considering that the study employed survey data, it was imperative to carry out some sensitivity test using the most common which is the test for multicolinearity. It tests the extent to which the variables of interest in the study correlates with each other since its incidence will lead to bias results. This is seen from the table showing the results of the variance inflation factor (VIF)

Table 1.Results of VIF Test for Multicollinearity

\begin{tabular}{|l|c|c|}
\hline Variables & VIF & 1/VIF \\
\hline Digital Transfer & 2.61 & 0.383373 \\
\hline Digital Payments & 2.53 & 0.395630 \\
\hline Digital Savings & 2.47 & 0.404835 \\
\hline Digital Withdrawals & 1.95 & 0.513595 \\
\hline Mean VIF & $\mathbf{2 . 3 9}$ & \\
\hline
\end{tabular}

According to Heckman (2015) the rule of thumb commonly used in practice is that if a VIF is $>10$, then there is the presence of high multicollinearity amongst the independent variables. In this result, we had a mean VIF of 2.39 which signified we are in good shape and thus proceeded with the regression analysis. This confirmed the hypothesis of no multicollinearity among the independent variables in the regression model.

\section{The regression model}

To analyse the primary data in order to get an insight of the influence of digital financial services on the profitability of commercial banks in 
Cameroon, this study adopted and modified the model of Ngumi (2013) who carried out a similar study using multiple linear regression model even though with different variables of interest. In testing the hypothesis, this study therefore made use of the following linear survey regression model; Prof. $=\beta 0+\beta 1$ (D.S.S) $+\beta 2$ (D. T.S) $+\beta 3$ (D.W.S) $+\beta 4$ (D.P.S) $+\mu \mathrm{i}$

The above model shows that the explained variable was profitability (Prof) of commercial banks measured using questions that captured return on assets for commercial banks that were answered by bank staff. The explanatory variables on the other hand included; Digital Savings Services (DSS), Digital Transfer Services (DTS), Digital Withdrawal Services (DWS), and Digital Payment Services (DPS) while $\mu$ i represents the error term.

\section{Test of significance of the model and model summary}

It is important to test the significance of the overall model so that policy makers will be assured of the reliability and validity of the research instrument and the variables used in the model so as to be more confident that the results of the findings are unbiased and instills confidence in them when making decisions. This can be seen from the model summary table.

Table 2a.Significance of the model and Model Summary

\begin{tabular}{|c|c|c|c|c|c|}
\hline \multicolumn{6}{|c|}{ Model Summary } \\
\hline \multirow[t]{2}{*}{ Model } & \multicolumn{3}{|c|}{ Change Statistics } & \multirow[b]{2}{*}{ Df2 } & \multirow[b]{2}{*}{$\begin{array}{l}\begin{array}{l}\text { Sig. F } \\
\text { change }\end{array} \\
\end{array}$} \\
\hline & $\begin{array}{l}\text { R Square } \\
\text { Change }\end{array}$ & $\begin{array}{l}\text { F } \\
\text { Change }\end{array}$ & df1 & & \\
\hline 1 & 0.4876 & 11.22 & 4 & 26 & 0.000 \\
\hline
\end{tabular}

Based on table $2 \mathrm{a}$ an $\mathrm{R}$ square value of 0.4876 implies $48 \%$ of the variations in the profitability of commercial banks are caused by joint variations in the use of digital transfer services, Digital Saving services, Digital Withdrawal services and Digital Payment services. Consequently 0.52 or $52 \%$ of the variations in profitability are not accounted for by the study's model on digital financial services but caused by the error term. The forecasting power of this is confirmed by the significance of the $\mathrm{P}>\mathrm{F}(0.00)$ which is significant even at $10 \%$ so that the predictions based on digital financial service-profitability model specified in this study could be held at 90\% confidence level making the findings suitable for generalizations. To move forward, the results of the survey linear regression model was employed to assess the influence of these variables on Commercial Bank Profitability.

Table $2 b$ brings out the results of the independent variable influence on the dependent variable (Profitability) 
Table 3b. Survey Linear Regression Results

\begin{tabular}{|l|l|l|l|l|l|l|}
\hline Linearized & Coef. & Std. Error & $\mathbf{t}$ & P>|t|t(Sig) & $95 \%$ Conf. Interval \\
\hline Profitability & & & & & \\
\hline Digital Transfers & 0.5169242 & 0.2416263 & 2.14 & 0.041 & 0.0227429 & 1.011105 \\
\hline Digital Savings & 0.2917238 & 0.0833358 & 3.50 & 0.002 & 0.121283 & 0.4621645 \\
\hline $\begin{array}{l}\text { Digital } \\
\text { Withdrawals }\end{array}$ & 0.5512949 & 0.2778834 & 1.98 & 0.057 & -.0170404 & 1.11963 \\
\hline Digital Payments & -0.760525 & 0.196645 & -3.87 & 0.001 & -1.162709 & -.3583409 \\
\hline Cons & 1.80453 & 1.399488 & 1.29 & 0.207 & -1.057744 & 4.666804 \\
\hline
\end{tabular}

\section{Findings}

\section{Summary of Findings}

The regression result above shows a $90 \%$ confidence level. From the results, Digital Transfers had a positive effect on the profitability of commercial banks in Cameroon to the extent that a unit increase in Digital Transfer services of commercial banks resulted to a 0.5169242 standard increase in profitability. This is in line with the a priori expectation of this paper and it is also statistically significant at $10 \%$ level given that the p-value 0.041 is less than the $10 \%$ threshold. Thus we rejected the null hypothesis that states that digital transfer services have no influence on the profitability of commercial banks in Cameroon. As a result, serious considerations should be given to Digital Transfer Services when examining measures to improve bank profitability.

In addition, in accordance with the a priori expectation, Digital Savings Services of commercial banks had a positive influence on the profitability of commercial banks in Cameroon. Precisely, a unit increase in Digital Savings services leads to a 0.2917238 standard increase in the profitability of commercial banks This is statistically significant at $10 \%$ level since it had a p-value of 0.002 less than $10 \%$ threshold with a positive | t |value. Thus we rejected the null hypothesis which states that digital Savings services have no influence on the profitability of commercial banks in Cameroon. It is therefore of great interest for policy makers to know that Digital Savings services are an important component of bank profitability.

Furthermore, the regression result reveals that Digital Withdrawal Services of commercial banks had a positive influence on the profitability of commercial banks in Cameroon. This means that a unit increase in Digital Withdrawals services by commercial banks, will lead to a 0.5512949 standard increase in the profitability of commercial banks in Cameroon with a $10 \%$ level of significance given that it has a p-value of 0.057 less than $10 \%$ threshold. This is in accordance with the a priori expectation of this study. Thus we rejected the null hypothesis that states that digital withdrawal 
services have no influence on the profitability of commercial banks in Cameroon. As a result, serious considerations should be given to Digital Withdrawal services when examining measures to improve on the profitability of commercial banks.

To add, contrary to a priori expectation, the results on Digital Payment services indicate that a unit increase in Digital Payment services leads to a drop in the profitability of commercial banks by 0.760525 units. However, this variable is still statistically significant at $10 \%$ since the corresponding p-value 0.001 is less than $10 \%$ threshold. Thus we fail to reject the null hypothesis that states that digital payment services have no influence on the profitability of commercial banks in Cameroon. Thus policy wise, focus should be given to Digital Payments when considering factors that determine the profitability of commercial banks in Cameroon since this variable was still found significant.

Going by the constant term of 1.80453 , it shows that without the use of digital financial services, commercial banks will still make profit worth 1.80453. However, this value is insignificant even at $10 \%$ level of significance since it had a p-value of 0.207 is more than $10 \%$ threshold with a high standard error of 1.399488 .

\section{Discussion of Findings}

The findings from the study generally, reveals that we reject the null hypothesis in favour of the alternative hypothesis which states that digital financial services have an influence on the profitability of commercial banks in Cameroon at $10 \%$ level of significance.

Looking at each of the variables, the results on the influence of Digital Transfers Services on the profitability of commercial banks in Cameroon was positive and significant. These findings are in conformity with the a priori expectations of this study and works of other authors such as (Ogare, 2013) who concluded that digital transfer is significant in explaining profitability of commercial banks. More so, a similar study carried out in Pakistan by Sana, Mohammad, Hassan \& Momina (2011) found that digital transfer services reduce costs, saves time, improves accuracy, improves reliability and quality of services and eventually leads to improved profitability for banks.

Furthermore, for Digital Payments, the results had a negative coefficient, meaning that Digital Payments Services negatively influence the profitability of commercial banks in Cameroon. This is however not in line with the economic expectation of this study as one will expect that the provision of digital payment services for banking transactions would have boosted economic activities therefore increasing the profits made from the bank's perspectives. There are, however, diverse results from existing 
literature on this variable.Boateng \&Nagaruju (2020) noted that E-zwich (the brand name for the National Switch and Smart card payment system) related a negative relationship with Ghanaian Bank profit levels. The reason raised for this was due to the scarcity of E-zwich machines that were supposed to be made available by banks. To add, these findings are in conformity with the findings of Takon et al., (2019). Theynoted that digital payments proxied by Automated Teller Machine (ATM) transactions, Point of Sales (POS) transactions, Mobile Payment (MP) transactions and Web Payment (WP) Transactions has a negative and significant impact on bank efficiency proxied by bank overhead cost both in the long and short run. This however, points to the increasing cost associated with the installation of an ATM in a particular physical location. Unlike mobile payment in which the customer bears the cost of the phone with which to perform the transactions, POS and ATM are born by the financial institutions that have to make it available to their customers for effective dissemination of financial services. However, the works of Boateng \& Nagaruju (2020), shows that Gh-Link a local electronic payment ecosystem based on the domestic Automated Teller Machines (ATM) card with channels such as ATM, POS and Web exhibited a positive relationship with the profitability of Ghanaian deposit money banks.

Again, it can be seen that, the results on the influence of Digital Savings Services and profitability of commercial banks in Cameroon was positive and significant. This is in conformity with economic expectations of the study and existing literature and it corroborates with the works of Chindudzi et al.,(2020) whose results shows that an increase in digital savings or online deposits will lead to a significant increase in Return on Assets (ROA) of banks precisely, the coefficient for digital savings was $\beta_{1}=$ 0.656533 and $\mathrm{P}=0.0000<0.05$ significant at the $1 \%$ threshold and $99 \%$ confidence interval level. Still in Zimbabwe, similar results were seen in the works of Wadesango\& Magaya (2020) who concluded that Return on Assets (ROA) in Commercial Bank of Zimbabwe (CBZ) increased in upwards trends due to an increase in online customer deposits through digital banking platforms. The coefficient of digital savings shows that $\beta_{1}=0.656533$ and $\mathrm{P}=0.0000<0.05$. The implication is that an increase in online savings or customer deposits would lead to a significant increase in ROA in commercial Banks locally. Though existing literature on digital savings and its influence on bank profitability are limited, so far literature on contrary findings is scarce.

In line with Digital Withdrawals, the study's results show that there is a positive significant relationship between digital withdrawal services and bank profitability. These findings are in line with the prior expectations and existing literature for the study. The results are in line according to the 
findings of Vekya (2017) whose results show that there is a positive significant relationship between digital withdrawals and bank profitability. They concluded that a unit increase in Digital Withdrawals leads to an increase in Return on Assets by 1.66 units. Existing literature on digital withdrawal and bank profitability is however scarce. This points to the absence of any contrary findings.

\section{Conclusion}

From the results, the study concluded that digital financial services of commercial banks influence the profitability of commercial banks in Cameroon. Specifically, digital savings, digital withdrawals and digital transfer services have a positive and significant influence on the profitability of commercial banks in Cameroon. Digital payment services on the other hand had a negative coefficient yet significant influence. The rendering of digital financial services by commercial banks in Cameroon has a great ability of significantly improving bank profit levels which will further lead to increased returns to shareholders. This is as a result of banks making use of innovative services that have enabled them to make additional income different from their traditional sources, particularly non-interest driven income.

To recommend, this is a call for concern for commercial bank managers and shareholders to ensure they provide robust digital payment services that are cost effective and efficient so as to generate more profit. The reason for the negative coefficient of digital payment could be that most shops in Cameroon do not yet have point of sales terminals that can facilitate payments digitally as such their uses are limited which further reduces the commission generated from the provision of such a service. Bank managers therefore should make sure that their payment services are available in bigger shops particularly those found in the heart of cities like Douala Yaounde, Limbe and even Buea. Again, bank managers could encourage more digital payments than physical cash payments within their institutions. As a result, with reduced cost of rendering such a service and encouraging its use, this may tend to increase the amount of profit banks generate from their digital payment services.

If bank mangers and policy makers in the banking industry provide robust digital services, it will go a long way to increase the income generated from commission driven services. This paper therefore recommends that management of banks and policy makers in the banking industry should not only focus on rendering digital financial services but services that are efficient and effective. If this is done, then the result will be reduced waiting time, break bottlenecks, make transactions faster, reduced cost of rendering banking services and consequently growth in profitability for commercial 
banks. Commercial Banks in Cameroon will also pay their own quota to curb the recent health crisis COVID-19 as customers will no longer crowd the banks for services that could be rendered digitally. However, this study is limited due to the unavailability of secondary data to complement the primary data.

\section{References:}

1. Alubisia, B., Githi, W., \& Mwangi, M. (2018). Effect of Technology Based Financial Innovations on Non-Interest Income of Commercial Banks in Kenya. European Scientific Journal. Vol.14, No.7 ISSN: 1857 - 7881 (Print) e - ISSN 1857- 7431

2. Ayuketang, N. (2018). Impact of Technology on E-Banking; Cameroon Perspectives. International Journal of Advanced Networking and Applications. Vol. 09 Issue.

3. Boateng, K \& Nagaraju, Y. (2020). The Impact of Digital Banking on the Profitability of deposit money banks: Evidence from Ghana. International Journal of Research in Finance and Management.

4. Barry, N. (2018). Digital Savings. What do we know about the Impact on Clients?

5. Chindudzi, G., Maradze, T. \& Nyoni, T. (2020). The impact of Digital Banking on the Performance of Commercial Banks in Zimbabwe

6. Etikan, I., Sulaiman, M. \& Alkassim, R. (2016). Comparison of Convenience Sampling and Purposive Sampling in Africa.

7. Galazova, S., \& Magomaeva (2019). The Transfomation of Traditional Banking Activity in Digital. The International Journal of Economics and Business Adminstration. Volume VII, Special Issue 2, 2019

8. Heckman, E. (2015). What in the World is a VIF?

9. Kambale, L.(nd). Digital Financial Services. The case of Malawi

10. Karmal, K., Sulieman, I., \& Piirainen, M. (2017). Digitalisation of the Financial Sector and Change. Management.

11. Kemboi, B. (2018). The Effect of Financial Technology on the Financial Performance of Commercial Banks in Kenya.

12. Ketterer, A.(2017). Digital Finance: New Time Challenges, New Opportunities

13. Lamberton, C. \& Stephen, A. (2016). A Thematic Exploration of Digital Social Media and Mobile Marketing: Research Evolution from 2000 to 2015 and an Agenda for future inquiry.

14. LeHouerou, P. (2018). How Technology id Delivering better access to financial services 
15. Sana, H., Mohammad, K., Hassan, S.,\& Momina, A(2011). The impact of E- banking on the Profitability of Commercial Banks. A Study of Pakistani Bank. Journal of Public Administration and Governance Vol.1 ISSN 2161-7104

16. Limunga, C. (2019). Cameroonian Banks to Digitalize for Efficiency.

17. Mueni, B. (2017). The Influence of Digitalisation on the Performance of Digitalized Commercial Banks in Kenya.

18. Ngumi (2013). Effects of Bank Innovation on Commercial Banks in Kenya

19. Ogare, O. (2013). The effect of Electronic Banking on the financial performance of commercial banks in Kenya

20. Porkelsson, S. (2017). Digitalisation in Consumer Banking. How Will Digitalisation Affect Consumer Banking in 10 Years?

21. Saab S. \& Vacher J. (2007). Banking Sector Integration and Competition in CEMAC. IMF Working Paper WP/07/03. International Monetary Fund

22. Scott, V., Reenen, J.\& Zachariadis, M. (2017). The Long-Term Effect of Digital Innovation on Bank. Performance: An Empirical Study of SWIFT Adoption in Financial Services; Journal of Economic Literature No. 20.

23. Takon, M., Nsofor, S, , Ugochukwu, S., Nwonye, N., \& Ekeh, C. (2019). Impact of Digital Payment System on the Efficiency of the Nigerian Banking Sector. Journal of Economics, Finance and Accounting Studies (JEFAS)

24. Vekya, M. (2017). Impact of Electronic Banking on the profitability of commercial banks in Kenya. Journal of Technology and System.

25. Wadesango, N., \& Magaya, B(2020). The Impact of Digital Banking Services on the Performance of commercial Banks in Zimbabwe. Journal of Management Information and Decision Science. Volume 23 Special

\section{Appendix One \\ Research Instrument \\ Questionnaire}

I am called Ngwengeh Brendaline Beloke a Ph.D student from the University of Buea. I wish to solicit your time to respond to this questionnaire. The questionnaire is meant to collect data regarding the Influence of Digital Financial Services on the Performance of Commercial Banks in Cameroon. Information provided will be used strictly for academic purpose and will be kept confidential.

Hint: Please tick the bracket corresponding to the right answer 


\section{GeneralInformation}

\section{SECTION A: Demographic Information}

Gender: Male: [ ]

Female: [ ]

Age: 20-30 : [ ] 30-40: [ ] 40-60: [ ] 60 and above: [ ]

Education: O' Levels: [ ] A' Levels: [ ] First Degree [ ] Masters

[ ] Maters and above [ ]

Marital Status: $\quad$ Single [ ] Married [ ] Divorced [ ]

Role: Top Level Manager [ ] Middle Level Manager [ ] Lower Level Manager [ ]

Longevity in Service: <1 year [ ] 1-3 years [ ] 4-6years [ ] 6-9 years [] 10 years and above [ ]

Income Level : $<250.000$ [ ] 250.000-500.000 [ ] above 500.000 [ ]

\section{SECTION B: Digital Financial Services}

\begin{tabular}{|l|l|l|l|l|l|}
\hline $\begin{array}{l}\text { DIGITAL FINANCIAL SERVICES: } \\
\text { A. DIGITAL PAYMENT SERVICES }\end{array}$ & SD & D & A & SA \\
\hline $\begin{array}{l}\text { Q1. Through digital means, banks pay the salaries of } \\
\text { staff and customers }\end{array}$ & & & & \\
\hline Q2.Bank pays their suppliers using digital means & & & & & \\
\hline $\begin{array}{l}\text { Q3. Through Digital services, banks are able to pay their } \\
\text { utility bills }\end{array}$ & & & & \\
\hline $\begin{array}{l}\text { Q4. It is possible to make payments for goods using } \\
\text { electronic means }\end{array}$ & & & & & \\
\hline $\begin{array}{l}\text { Q5.With digital financial services the volume of digital } \\
\text { payments has been increasing over the past 5 years }\end{array}$ & & & & & \\
\hline
\end{tabular}

\begin{tabular}{|l|l|l|l|l|l|}
\hline B. DIGITAL WITHDRAWAL SERVICES & SD & D & N & A & SA \\
\hline $\begin{array}{l}\text { Q6. Bank staff withdraw their salaries using digital } \\
\text { means }\end{array}$ & & & & & \\
\hline $\begin{array}{l}\text { Q7. With digital services, customers can withdraw } \\
\text { their salaries }\end{array}$ & & & & & \\
\hline $\begin{array}{l}\text { Q8. Bank customers have the opportunity to } \\
\text { withdraw their savings digitally }\end{array}$ & & & & & \\
\hline $\begin{array}{l}\text { Q9. Loans extended to customers can be withdrawn } \\
\text { online }\end{array}$ & & & & & \\
\hline $\begin{array}{l}\text { Q10.The Volume of Digital withdrawals has been } \\
\text { increasing with digital financial services over the } \\
\text { past 5 years }\end{array}$ & & & & & \\
\hline
\end{tabular}

\begin{tabular}{|l|l|l|l|l|l|}
\hline C. DIGITAL SAVING SERVICES & SD & D & N & A & SA \\
\hline Q11. The Bank offers digital savings services & & & & & \\
\hline Q12. Bank customers can make deposits into their & & & & & \\
\hline
\end{tabular}




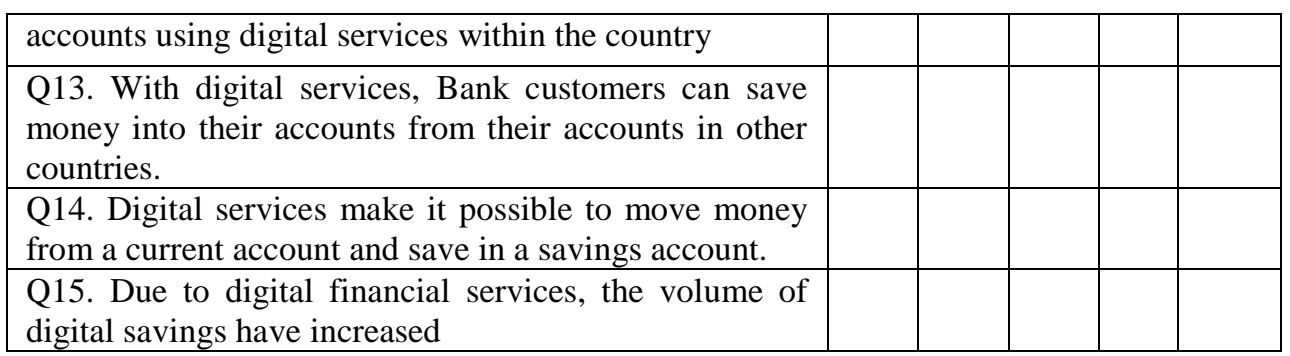

\begin{tabular}{|l|l|l|l|l|l|}
\hline D. DIGITAL TRANSFER SERVICES & SD & D & N & A & SA \\
\hline $\begin{array}{l}\text { Q16.With digital transfers, a bank customer can move } \\
\text { money from current account to another account within } \\
\text { the same bank }\end{array}$ & & & & & \\
\hline $\begin{array}{l}\text { Q17. Banks also do inter- bank transfers using digital } \\
\text { services }\end{array}$ & & & & & \\
\hline $\begin{array}{l}\text { Q18. Using digital services, a customer can transfer } \\
\text { money from one current account to the current account } \\
\text { of another bank within the country }\end{array}$ & & & & & \\
\hline $\begin{array}{l}\text { Q19. It is possible to transfer money from one bank } \\
\text { account to another foreign current bank account using } \\
\text { digital means. }\end{array}$ & & & & & \\
\hline $\begin{array}{l}\text { Q20.The volume of Digital transfers has increased over } \\
\text { the past } 5 \text { years with increased use of digital financial } \\
\text { services }\end{array}$ & & & & & \\
\hline
\end{tabular}

\section{SECTION C: Performance Of Commecial Banks}

\begin{tabular}{|l|l|l|l|l|l|}
\hline \multicolumn{1}{|c|}{ A. PROFITABILITY } & SD & D & N & A & SA \\
\hline $\begin{array}{l}\text { Q21. Over the years, the Gross income of the bank has } \\
\text { been increasing }\end{array}$ & & & & & \\
\hline $\begin{array}{l}\text { Q22.Net Operating Income generated by bank has been } \\
\text { on an increase }\end{array}$ & & & & & \\
\hline Q23 Return on equity has increased over the years & & & & & \\
\hline Q24. Net income of the bank has been increasing & & & & & \\
\hline Q25.Bank Return on assets has increased & & & & & \\
\hline
\end{tabular}

